Alvi, B. • M. Ariyanti · Y. Maxiselly

\title{
Pemanfaatan beberapa jenis urin ternak sebagai pupuk organik cair dengan konsentrasi yang berbeda pada tanaman kelapa sawit (Elaeis guineensis Jacq.) di pembibitan utama
}

\section{Utilization of livestocks urine as a liquid organic fertilizer with different concentrations on oil palm (Elaeis guineensis Jacq.) in main nursery}

Diterima : 30 Mei 2018/Disetujui : 1 Agustus 2018 / Dipublikasikan : 7 Agustus 2018

CDepartment of Crop Science, Padjadjaran University

\begin{abstract}
Seedling is an initial stage in the cultivation of oil palm, seed quality will affect the results that will be obtained later. Factor affecting the growth of seedlings of which the availability of nutrients which can be obtained from inorganic and organic fertilizer. Application of inorganic fertilizer without an organic fertilizer balanced can be damage the nature of the soil, necessitating organic fertilizer the urine of livestocks as organic liquid, adding organic liquid fertilizer to the soil, can help the plants to growth because organic liquid fertilizer of livestocks urine contain growth hormone for plants and easily absorbed to the plants. The research was conducted in Experimental Station of Ciparanje, Faculty of Agriculture, Padjadjaran University, Sumedang, from September 2017 to February 2018. Ordo of the soil used is Inceptisol. Precipitation type according to Schmidt and Ferguson's classification of type C with \pm 780 meters above sea level altitude. Experiment was using a randomized block design (RBD) with 11 treatments with 3 replications and the number of plants in each plot of 2 plants. The treatment consists the urine of cows, goats and rabbits with some concentration of $40 \mathrm{~mL} / \mathrm{L}$ of water, $120 \mathrm{~mL} / \mathrm{L}$ of water and $200 \mathrm{~mL} / \mathrm{L}$ of water as well as a comparison treatment, control (untreated) and the provision of urea fertilizer $3,3 \mathrm{~g} /$ plant. The results showed that the utilization some kinds of

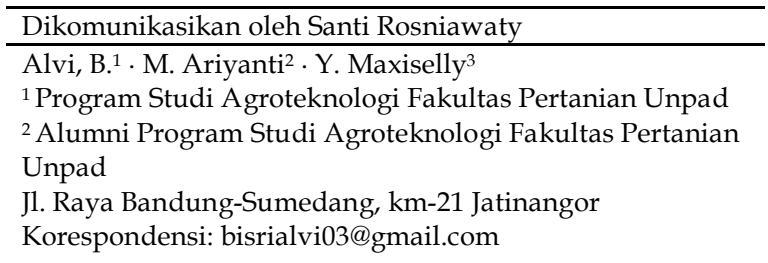

cattle urine provides a good effect on plant growth, which is reflected from the dry weight of the plant. Treatment goat's urine concentration $40 \mathrm{~mL} / \mathrm{L}$ of water and $120 \mathrm{~mL} / \mathrm{L}$ of water tends to affect on the dry weight shoot, dry weight root, and shoot root ratio on seedling oil palm.

Keywords: Livestock urine $\cdot$ Cow's urine $\cdot$ Goat's urine $\cdot$ Rabbit's urine $\cdot$ Oil palm

Sari. Pembibitan merupakan tahapan awal dalam budidaya tanaman kelapa sawit, kualitas bibit akan mempengaruhi hasil yang akan diperoleh nantinya. Faktor yang mempengaruhi pertumbuhan bibit diantaranya adalah ketersediaan unsur hara yang dapat diperoleh dari pemberian pupuk anorganik dan organik. Pemberian pupuk anorganik tanpa diimbangi pupuk organik dapat merusak sifat tanah, sehingga diperlukan pupuk organik yaitu dengan memanfaatkan urin ternak sebagai pupuk organik cair, dengan menambahkan pupuk organik cair pada tanah, maka dapat membantu proses pertumbuhan tanaman karena pupuk organik cair urin ternak mengandung hormon pertumbuhan bagi tanaman serta mudah diserap tanaman. Penelitian dilakukan di Kebun Percobaan Ciparanje, Fakultas Pertanian, Universitas Padjadjaran, Kabupaten Sumedang, pada bulan September 2017 sampai bulan Februari 2018. Ordo tanah yang digunakan adalah Inceptisol. Tipe curah hujan menurut klasifikasi Schmidt dan Ferguson bertipe C dengan ketinggian tempat $\pm 780 \mathrm{~m}$ dpl. Penelitian menggunakan rancangan acak kelompok (RAK) dengan 11 perlakuan yang 
diulang sebanyak 3 kali dengan jumlah tanaman di setiap plot 2 tanaman. Perlakuan terdiri dari pemberian urin sapi, kambing dan kelinci dengan konsentrasi $40 \mathrm{~mL} / \mathrm{L}$ air, $120 \mathrm{~mL} / \mathrm{L}$ air dan $200 \mathrm{~mL} / \mathrm{L}$ air, serta perlakuan kontrol (tanpa perlakuan) dan pemberian pupuk urea 3,3 g/tanaman. Hasil penelitian menunjukkan bahwa pemanfaatan urin ternak memberikan pengaruh baik terhadap pertumbuhan tanaman, yang tercermin dari bobot kering tanaman. Perlakuan urin kambing konsentrasi $40 \mathrm{~mL} / \mathrm{L}$ air dan $120 \mathrm{~mL} / \mathrm{L}$ air cenderung berpengaruh baik terhadap bobot kering tajuk, bobot kering akar, dan nisbah tajuk akar bibit kelapa sawit.

Kata Kunci: Urin ternak • Urin sapi • Urin kambing • Urin kelinci - Kelapa sawit.

\section{Pendahuluan}

Tanaman kelapa sawit (Elaeis guineensis Jacq.) merupakan salah satu komoditas tanaman perkebunan andalan Indonesia, karena mampu menjadi penyumbang devisa terbesar untuk negara. Produksi kelapa sawit Indonesia tahun 2014 mencapai 29.278.189 ton dan diikuti oleh Malaysia sebesar 19.667.016 ton (FAO,2016). Peningkatan produksi kelapa sawit di Indonesia menurut Nasution dkk (2014) dipengaruhi oleh pertambahan luas lahan yang terus meningkat setiap tahunnya, dan untuk memperoleh produksi maupun produktivitas yang tinggi pada tanaman kelapa sawit juga perlu adanya penanganan yang sesuai pada saat pembibitan Ramadhaini dan Wachjar (2014).

Pembibitan kelapa sawit merupakan tahapan awal dalam teknik budidaya tanaman kelapa sawit, yang juga akan mempengaruhi hasil yang diperoleh nantinya. Kecukupan unsur hara yang disesuaikan dengan kebutuhan tanaman, akan menghasilkan bibit kelapa sawit yang vigor dan adaktif ketika dipindahkan ke lapangan. Unsur hara kelapa sawit dapat diperoleh dari pemberian pupuk anorganik dan organik. Pemberian pupuk anorganik cenderung memberikan pengaruh yang lebih cepat, akan tetapi pemberian pupuk anorganik yang tidak berimbang dapat mengakibatkan $\mathrm{pH}$ tanah menurun, meningkatnya konsentrasi garam dalam larutan, merusak struktur tanah, turunnya kadar bahan organik tanah sehingga dapat menurunkan produktivitas tanah (Isnaini, 2006).
Penggunaan pupuk organik dari urin ternak merupakan salah satu alternatif yang dapat digunakan untuk mengatasi permasalahan kerusakan tanah akibat pemberian pupuk anorganik yang tidak berimbang. Penggunaan pupuk organik cair (POC) dari urin hasil metabolisme ternak memberikan manfaat, seperti membantu pertumbuhan tanaman, karena kandungan $\mathrm{N}$ dan $\mathrm{K}$ yang sangat tinggi, mengandung hormon pertumbuhan bagi tanaman serta mudah diserap tanaman, menurut Sosrosoedirdjo dkk (1981) yang dikutip dari Budhie, (2010). Sapi, kambing dan kelinci merupakan beberapa jenis ternak yang urinnya dapat dimanfaatkan sebagai POC pada tanaman kelapa sawit.

Hasil penelitian tentang kandungan di dalam urin ternak dikemukakan beberapa peneliti diantaranya, Anty, (1980) yang dikutip dari Mardalena, (2009), urin sapi mengandung hormon IAA (Indole Acetate Acid) yang berfungsi sebagai hormon untuk perkembangan sel sehingga pertumbuhan tanaman akan tumbuh lebih cepat. Menurut Sitorus dkk (2015), urin kambing bisa dijadikan sebagai sumber pupuk organik cair bagi tanaman, karena mengandung $\mathrm{N}$ dan K yang tinggi, serta mengandung hormon untuk pertumbuhan tanaman, kemudian berdasarkan hasil penelitian dari badan penelitian ternak tahun 2005 dikutip oleh Marpaung dkk., (2014), kotoran dan urin kelinci dapat dijadikan sebagai pupuk dan pestisida untuk tanaman.

Beberapa hasil penelitian menunjukkan adanya pengaruh baik pada tanaman dari pemanfataan urin ternak. Penelitian Syarovy dkk (2015), menunjukkan bahwa pemberian urin sapi konsentrasi 5\% memberikan pengaruh terhadap pertambahan jumlah pelepah kelapa sawit, bobot kering dan serapan hara N, P, K, $\mathrm{Ca}$, dan $\mathrm{Mg}$ pada bibit kelapa sawit di pembibitan utama. Penelitian Sarah dkk (2016), pemberian pupuk organik cair urin kambing yang difermentasi dengan konsentrasi 200 ml/1 memberikan pertumbuhan vegetatif terbaik pada tanaman lada. Penelitian Rosniawaty dkk (2017), penggunaan media tanah dan kompos kulit kopi dengan perbandingan 2:1 atau 3:1 serta pemberian urin kelinci memberikan pengaruh terbaik terhadap tinggi tanaman, diameter batang dan jumlah daun tanaman kopi, dan penggunaan media tanah dan kompos daun (3:1) dengan pemberian urin kelinci 
memberikan pengaruh terbaik pada volume akar dan luas daun.

Berdasarkan uraian di atas maka perlu dilakukan penelitian untuk mengetahui pengaruh pemanfaatan beberapa jenis urin ternak sebagai pupuk organik cair terhadap pertumbuhan tanaman kelapa sawit dan mengetahui tingkat konsentrasi yang akan memberikan pengaruh terbaik terhadap pertumbuhan tanaman kelapa sawit di pembibitan utama.

\section{Bahan dan Metode}

Penelitian ini dilakukan di kebun percobaan Ciparanje Fakultas Pertanian Universitas Padjadjaran pada ketinggian $\pm 780 \mathrm{~m} \mathrm{dpl}$, dengan ordo tanah Inceptisol, dan memiliki tipe iklim C berdasarkan klasifikasi menurut Schmidt dan Ferguson tahun 1951. Penelitian ini dilaksanakan mulai bulan September 2017 sampai Februari 2018.

Alat dan bahan yang digunkana; cangkul, oven, timbangan analitik, gelas ukur, ember, emrat, label, alat dokumentasi, alat tulis, bahan tanam bibit kelapa sawit varietas Simalungun umur 5 bulan, tanah berordo Inceptisol, pupuk Urea, pupuk cair urin ternak, dan polybag.

Pada penelitian ini digunakan rancangan acak kelompok (RAK) dengan 11 perlakuan yang diulang sebanyak tiga kali dan setiap plot terdiri dari dua tanaman, sehingga jumlah tanaman total yang diperlukan adalah 66 tanaman. Berikut ini merupakan perlakuan yang digunakan pada penelitian ini:

$\mathrm{A}=$ tanpa perlakuan (kontrol)
$\mathrm{B}=$ pupuk urea $3,3 \mathrm{~g} /$ tanaman $/$ bulan

$\mathrm{C}=$ urin sapi konsentrasi $40 \mathrm{~mL} / \mathrm{L}$ air

$\mathrm{D}=$ urin sapi konsentrasi $120 \mathrm{~mL} / \mathrm{L}$ air

$\mathrm{E}=$ urin sapi konsentrasi $200 \mathrm{~mL} / \mathrm{L}$ air

$\mathrm{F}=$ urin kambing konsentrasi $40 \mathrm{~mL} / \mathrm{L}$ air

$\mathrm{G}=$ urin kambing konsentrasi $120 \mathrm{~mL} / \mathrm{L}$ air

$\mathrm{H}=$ urin kambing konsentrasi $200 \mathrm{~mL} / \mathrm{L}$ air

$\mathrm{I}=$ urin kelinci konsentrasi $40 \mathrm{~mL} / \mathrm{L}$ air

$\mathrm{J}=$ urin kelinci konsentrasi $120 \mathrm{~mL} / \mathrm{L}$ air

$\mathrm{K}=$ urin kelinci konsentrasi $200 \mathrm{~mL} / \mathrm{L}$ air

Analisis statistik untuk mengetahui pengaruh perlakuan dengan menggunakan uji F, apabila signifikan, dilanjiutkan dengan uji Duncan pada taraf kepercayaan 95\%.

\section{Hasil dan Pembahasan}

Data iklim yang diperoleh dari Stasiun Cuaca Fakultas Pertanian Universitas Padjadjaran menunjukkan bahwa rata-rata curah hujan selama penelitian yaitu $262,5 \mathrm{~mm}$ / bulan dengan temperatur udara rata-rata $23,3^{\circ} \mathrm{C}$, serta memiliki rata-rata kelembapan udara per bulannya $88,9 \%$. Curah hujan rata-rata yang menjadi syarat tumbuh tanaman kelapa sawit yaitu $1.500-4.000 \mathrm{~mm} /$ tahun atau $125-333 \mathrm{~mm} /$ bulan, suhu optimal $24-28^{\circ} \mathrm{C}$, dengan kelembapan udara optimal yang ideal adalah $80-90 \%$ (Balitbangtan, 2008). Berdasarkan hasil analisis data curah hujan dan kelembapan selama penelitian, mendukung pertumbuhan kelapa sawit, sedangkan temperatur selama penelitian tergolong kurang sesuai, karena berada dibawah syarat optimal pertumbuhan kelapa sawit.

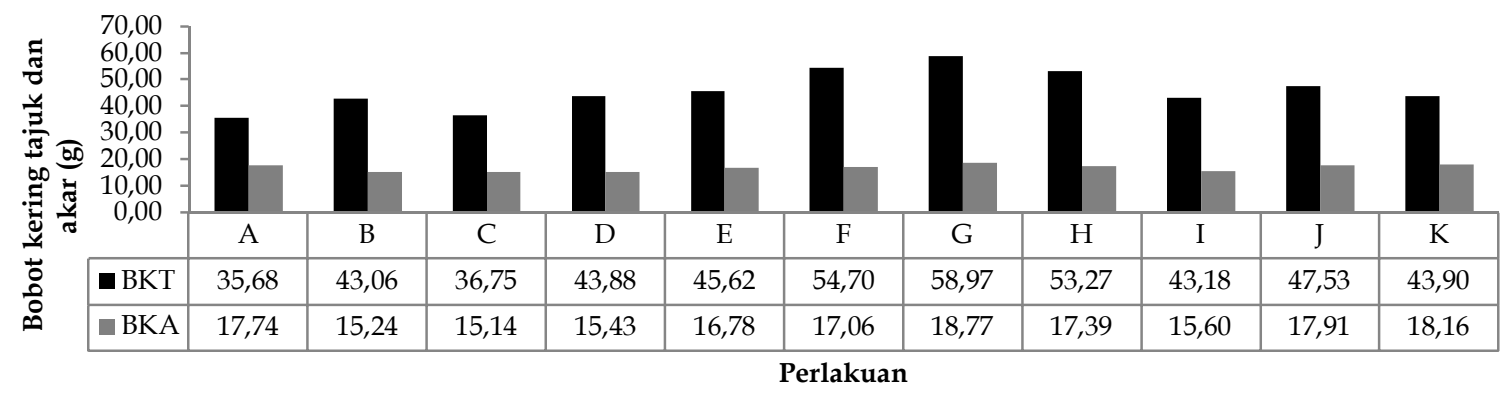

Gambar 1. Diagram pengaruh pemberian POC terhadap bobot kering tajuk dan bobot kering akar kelapa sawit di pembibitan utama

Keterangan: Diagram dengan nilai rataan perlakuan. ( $\mathrm{A}=$ Tanpa perlakuan; $\mathrm{B}=$ Pupuk urea 3,3 gram/tanaman; $\mathrm{C}=$ Urin sapi konsentrasi $40 \mathrm{ml} / 1$ air; D = Urin sapi konsentrasi $120 \mathrm{ml} / 1$ air; $\mathrm{E}=$ Urin sapi konsentrasi 200 ml/1 air; $\mathrm{F}=$ Urin kambing konsentrasi $40 \mathrm{ml} / 1$ air; $\mathrm{G}=$ Urin kambing konsentrasi $120 \mathrm{ml} / \mathrm{l}$ air; $\mathrm{H}=$ Urin kambing konsentrasi $200 \mathrm{ml} / \mathrm{l}$ air; I = Urin kelinci konsentrasi $40 \mathrm{ml} / 1$ air; J = Urin kelinci konsentrasi $120 \mathrm{ml} / 1$ air; $\mathrm{K}=$ Urin kelinci konsentrasi $200 \mathrm{ml} / 1$ air) 
Tabel 1. Hasil analisis kandungan urin.

\begin{tabular}{lccc}
\hline Jenis Analisis & $\begin{array}{c}\text { Urin } \\
\text { Sapi }\end{array}$ & $\begin{array}{c}\text { Urin } \\
\text { Kambing }\end{array}$ & $\begin{array}{c}\text { Urin } \\
\text { Kelinci }\end{array}$ \\
\hline pH & 8,25 & 8,71 & 8,21 \\
N-total (\%) & 0,23 & 1,13 & 0,1 \\
P2O5 (\%) & 0,07 & 0,05 & 0,04 \\
K20 (\%) & 1,70 & 7,90 & 2,11 \\
\hline
\end{tabular}

Berdasarkan Tabel 1. dapat dilihat bahwa hasil analisis kandungan urin yang diperoleh dari Laboratorium Kesuburan Tanah dan Nutrisi Tanaman Fakultas Pertanian Universitas Padjadjaran, kandungan hara urin kambing lebih tinggi dibandingkan dengan kandungan unsur hara urin lainnya, terutama pada kandungan $\mathrm{N}$ dan $\mathrm{K}$.

Bobot Kering Tajuk dan Akar. Berdasarkan Gambar 1 dapat dilihat bahwa pemberian POC urin ternak pada bibit kelapa sawit tidak berpengaruh nyata terhadap bobot kering tajuk dan akar bibit kelapa sawit di pembibitan utama, akan tetapi perlakuan G (urin kambing konsentrasi $120 \mathrm{~mL} / \mathrm{L}$ air) cenderung meningkatkan bobot kering tajuk dan akar bibit kelapa sawit. Pemberian urin kambing dengan konsentrasi $120 \mathrm{~mL} / \mathrm{L}$ air apabila dibandingkan dengan perlakuan A (kontrol) dan perlakuan B (pupuk urea 3,3 g/tanaman) mampu meningkatkan bobot kering tajuk dan bobot kering tajuk bibit kelapa sawit berturut-turut sebesar 65,27\% (tajuk), 5,81\% (akar) dan 36,95\% (tajuk), 23,16\% (akar).

Bobot kering tajuk dan akar merupakan tolak ukur untuk menentukan tingkat metabolisme dari suatu tanaman. Pernyataan yang dikemukakan oleh Fried and Hademenos (2000) yang dikutip dari Afrillah dkk (2015) menyatakan bahwa akumulasi bahan kering (tajuk dan akar) mencerminkan kemampuan tanaman dalam menangkap cahaya matahari melalui proses fotosintesis dan interaksi dengan faktor lingkungan lainnya. Bobot kering tanaman yang baik akan mencerminkan pertumbuhan tanaman yang baik, dengan meningkatnya pertumbuhan vegetatif bibit kelapa sawit maka akan meningkatkan bobot kering dari bibit kelapa sawit tersebut (Yanto dkk., 2016).

Bobot kering tanaman merupakan patokan untuk melihat pengaruh pemberian POC terhadap kualitas tanaman. Pernyataan yang dikemukakan oleh Gardner, (1991) yang dikutip dari Yanto dkk (2016), meningkatnya pertumbuhan vegetatif tanaman seperti akar, batang dan daun akan mendorong meningkatnya kandungan karbohidrat yang tercermin pada berat kering suatu tanaman.

Nisbah Tajuk Akar. Berdasarkan Gambar 2 dapat dilihat bahwa pemberian POC urin ternak pada bibit kelapa sawit tidak berpengaruh nyata terhadap nisbah tajuk akar bibit kelapa sawit di pembibitan utama, akan tetapi perlakuan F (urin kambing konsentrasi 40 $\mathrm{ml} / 1$ air) cenderung berpengaruh baik terhadap nisbah tajuk akar bibit kelapa sawit.

Nisbah tajuk akar merupakan cerminan untuk melihat efisiensi akar dalam mendukung pembentukan tajuk tanaman. Menurut Sitompul dan Guritno (1995), yang dikutip dari Budhie (2010), menyatakan tanaman yang mempunyai

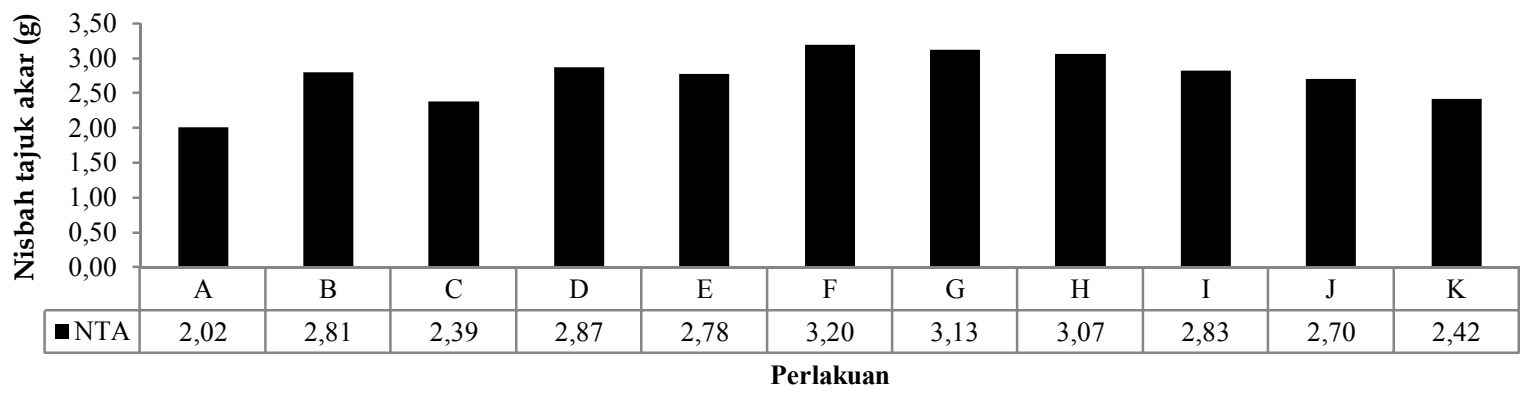

Gambar 2. Diagram pengaruh pemberian POC terhadap nisbah tajuk akar kelapa sawit di pembibitan utama

Keterangan: Diagram dengan nilai rataan perlakuan. ( $\mathrm{A}=$ Tanpa perlakuan; $\mathrm{B}=$ Pupuk urea 3,3 gram/tanaman; $\mathrm{C}=$ Urin sapi konsentrasi $40 \mathrm{ml} / 1$ air; $\mathrm{D}=$ Urin sapi konsentrasi $120 \mathrm{ml} / 1$ air; $\mathrm{E}=$ Urin sapi konsentrasi $200 \mathrm{ml} / 1$ air; $\mathrm{F}=$ Urin kambing konsentrasi $40 \mathrm{ml} / 1$ air; $\mathrm{G}=$ Urin kambing konsentrasi $120 \mathrm{ml} / 1$ air; $\mathrm{H}=$ Urin kambing konsentrasi $200 \mathrm{ml} / 1$ air; I = Urin kelinci konsentrasi $40 \mathrm{ml} / 1$ air; J = Urin kelinci konsentrasi $120 \mathrm{ml} / 1$ air; $\mathrm{K}=$ Urin kelinci konsentrasi $200 \mathrm{ml} / 1$ air) 
rasio tajuk akar yang tinggi dengan bobot massa yang tinggi menunjukkan bahwa akar yang relatif sedikit cukup untuk mendukung pertumbuhan tanaman yang relatif besar dalam penyediaan air dan unsur hara.

Secara umum dapat dilihat bahwa pemberian POC urin ternak tidak memberikan pengaruh terhadap pertumbuhan bibit kelapa sawit yang tercerminkan dari hasil uji statistik yang dilakukan pada parameter bobot kering dan nisbah tajuk akar tanaman, akantetapi POC yang berasal dari urin kambing cenderung memberikan pengaruh baik dibandingkan dengan perlakuan lainnya. Pemberian urin kambing dengan konsentrasi $40 \mathrm{~mL} / \mathrm{L}$ air dan $120 \mathrm{~mL} / \mathrm{L}$ air memberikan pengaruh yang cenderung baik terhadap bobot kering tanaman dan nisbah tajuk akar tanaman kelapa sawit di pembibitan utama.

\section{Kesimpulan}

\section{Kesimpulan:}

1. Pemanfaatan urin ternak sebagai pupuk organik cair pada tanaman kelapa sawit di pembibitan utama tidak memberikan pengaruh terhadap pertumbuhan bibit kelapa sawit.

2. Pemanfaatan urin kambing dengan konsentrasi $40 \mathrm{~mL} / \mathrm{L}$ air dan $120 \mathrm{~mL} / \mathrm{L}$ air cenderung memberikan pengaruh yang baik terhadap bobot kering tajuk dan bobot kering akar serta nisbah tajuk akar tanaman kelapa sawit di pembibitan utama umur 5 bulan.

Saran. Perlu dilakukannya penelitian lebih lanjut dengan menambahkan variasi dari konsentrasi urin, terutama urin kambing pada tanaman kelapa sawit di pembibitan utama, sehingga dapat diketahui konsentrasi yang mampu memberikan pengaruh yang nyata terhadap pertumbuhan tanaman.

\section{Daftar Pustaka}

Afrillah, M., F.E. Sitepu, dan C. Hanum. 2015. Respons pertumbuhan vegetatif tiga varietas kelapa sawit di pre nursery pada beberapa media tanam limbah. Online Agroteknologi 3(4): 1289-1295.

Balitbangtan. 2008. Teknologi Budidaya Kelapa Sawit. BUN/11/200. Bandar Lampung: Balai Besar Pengkajian dan Pengem- bangan Teknologi Pertanian.

Budhie, D.D.S. 2010. Aplikasi urin kambing peranakan etawa dan nasa sebagai pupuk organik cair untuk pemacu pertumbuhan dan produksi tanaman pakan legum. Skripsi Institut Pertanian Bogor. http:// repository.ipb.ac.id/jspui/bitstream/12345 6789/62986/1/D10dds.pdf. Diakses pada tanggal 4 September 2017

FAO. 2016. FAOSTAT_data_6-1-2017. Available at http://www.fao.org/faostat/en/\#data / QC. Dikases pada tanggal 1 Juni 2017

Isnaini, M. 2006. Pertanian Organik. Yogyakarta: Kreasi Wacana. Halaman 247-248. Diakses pada tanggal 9 Mei 2017

Mardalena. 2009. Respon pertumbuhan dan produksi tanaman mentimun (Cucumis sativus L.) terhadap urine sapi yang telah mengalami perbedaan lama fermentasi. Skripsi. Universitas Sumatera Utara

Marpaung, A.E., A. Lasmono, dan B.B. Karo. 2014. Efek tehnik penanaman dan pemberian urin kelinci terhadap pertumbuhan dan produksi tanaman kentang granola (Solanum tuberosum L.). Pros. Seminar Nasional Sains dan Inovasi Teknologi Pertanian: 285-297.

Nasution, S.H., C. Hanum, dan J. Ginting. 2014. Pertumbuhan bibit kelapa sawit (Elaeis guineensis Jacq.) pada berbagai perbandingan media tanam solid decanter dan tandan kosong kelapa sawit pada sistem Single Stage. Online Agroteknologi 2 (2337): 691-701Available at http://jurnal. usu.ac.id/index.php/agroekoteknologi/a rticle/viewFile/7076/2904.

Ramadhaini, R.F., dan A. Wachjar. 2014. Optimasi dosis pupuk majemuk npk dan kalsium pada bibit kelapa sawit (Elaeis guineensis Jacq.) di pembibitan utama. Agron.Indonesia 42(1): 52-58.

Rosniawaty, S., R. Sudirja, dan H. Hidayat. 2017. Pemanfaatan limbah organik sebagai media tanam dan aplikasi urin ternak pada pembibitan kopi (Coffea arabica 1 .). Kultivasi 16(1): 287-292.

Sarah, H. Rahmatan, dan Supriatno. 2016. Pengaruh pemberian berbagai konsentrasi urin kambing yang difermentasi terhadap pertumbuhan vegetatif lada (Piper nigrum L.). Ilmiah Mahasiswa Pend. Biologi 1(1): 1-9.

Sitorus, M.R., T. Irmansyah, dan F.E.T. Sitepu. 2015. Respons pertumbuhan bibit setek tanaman buah naga merah (Hylocereus 
costaricencis (Web) Britton \& Ross) terhadap pemberian auksin alami dengan berbagai tingkat konsentrasi. Agroteknologi 3(4): 1557-1565.

Syarovy, M., A. Purba, T.C. Hidayat, dan F. Hidayat. 2015. Respon pertumbuhan bibit kelapa sawit terhadap pemberian pupuk cair urin sapi. Pusat Penelitian Kelapa Sawit 23(3): 137-145.

Yanto, K., Adiwirman, dan Nurbaiti. 2016. Pemberian Pupuk Organik Cair terhadap Pertumbuhan Bibit Kelapa Sawit (Elaeis guineensis Jacq.) pada Pembibitan Utama. Jom Faperta 3(2): 1-12. 